\title{
Influence of Fiscal Policies and Labor Market Characteristics on Sustainable Social Insurance Budgets-Empirical Evidence from Central and Eastern European Countries
}

\author{
Adriana Florina Popa ${ }^{1, *}$, Stefania Amalia Jimon ${ }^{2}$, Delia David ${ }^{2}$ and Daniela Nicoleta Sahlian ${ }^{1}$ \\ 1 Department of Accounting and Audit, Bucharest University of Economic Studies, 010374 Bucharest, Romania; \\ daniela.sahlian@cig.ase.ro \\ 2 Department of Economic and Technical Sciences, Faculty of Economics, Computer Science and Engineering, \\ "Vasile Goldiș" Western University of Arad, 310045 Arad, Romania; jimon.stefania@uvvg.ro (S.A.J.); \\ delia.david@uvvg.ro (D.D.) \\ * Correspondence: adriana.popa@cig.ase.ro
}

\section{check for} updates

Citation: Popa, A.F.; Jimon, S.A.; David, D.; Sahlian, D.N. Influence of Fiscal Policies and Labor Market Characteristics on Sustainable Social Insurance Budgets-Empirical Evidence from Central and Eastern European Countries. Sustainability 2021, 13, 6197. https://doi.org/ $10.3390 /$ su13116197

Academic Editor: Klaus Reiner Schenk-Hoppé

Received: 20 April 2021

Accepted: 28 May 2021

Published: 31 May 2021

Publisher's Note: MDPI stays neutral with regard to jurisdictional claims in published maps and institutional affiliations.

Copyright: (c) 2021 by the authors. Licensee MDPI, Basel, Switzerland. This article is an open access article distributed under the terms and conditions of the Creative Commons Attribution (CC BY) license (https:/ / creativecommons.org/licenses/by/ $4.0 /)$.

\begin{abstract}
Social protection systems are a key factor for ensuring the long-term sustainability and stability of economies in the European Union, their reform being nowadays present in the political agenda of member states. Aging and the dependence on mandatory levies applied to the employed population on the labor market represent a threat for the sustainability of public social protection systems. In terms of sustainability, our purpose was to highlight the factors influencing social insurance budgets, considering the fiscal policies implemented in six countries of Central and Eastern Europe and their particular labor market characteristics. Therefore, a panel study based on a regression model using the Ordinary Least Squares method (OLS) with cross section random effects was used to determine the correlations between funding sources and labor market specific indicators. The data analyzed led to relevant results that emphasize the dependence of social insurance budgets on positive factors such as the average level of salaries, the share of compulsory social contributions, the unemployment rate, and the human development index, suggesting the continuing need for professional and personal development of the workforce.
\end{abstract}

Keywords: fiscal policies; social insurance budgets; sustainability; demographic transition; labor market; Central and Eastern Europe

\section{Introduction}

Budget revenues have an important role in the achievement of sustainable development goals in an economy. Social protection of the population has been a priority for all states of the world, regardless of political ideology, system of government, socio-economic system, culture, or religion. The International Labor Organization defines social protection as the way to ensure the right to health care and the right to financial security of children, elderly, and people who, due to accidents, disabilities, or pathologies, cannot carry out professional activities to obtain income [1]. Sabates-Wheeler and Devereux highlighted its role in reducing the social, economic, and financial vulnerability of the population [2], and Boadway and Keen supported the effectiveness of the state in organizing and operating social protection systems to achieve this goal [3].

Anderson and Pontusson indicated that the social security system can reduce job insecurity [4], while Sverke et al. brought evidence that welfare regimes and social policies can increase employee's performance [5]. Cortès-Franch et al. showed that welfare state regimes and job quality are important factors in determining the mental wellbeing of the population [6].

Most democratic states have implemented contributory welfare regimes, the public social protection systems being dependent on revenues collected from the labor market. 
From this perspective, the demographic situation of Central and Eastern European countries (CEE, from this point forward) puts a lot of pressure on public social protection systems financed by labor market contributions. Along with the reduction of the number of employed persons paying social contributions to the Social Insurance Budget, the budgetary revenues, needed to provide the necessary financial support to the beneficiaries, are also reduced.

With an aging population, the consolidation of social protection systems can be acquired only through sustainable economic development [7], encompassing three major sustainability dimensions: environmental, social, and economic [8]. According to the United Nations Organization 2030 Agenda for Sustainable Development, the complexity and interdependence of the sustainable development challenge brings together all the actors playing in the field, focusing, first of all, on how labor and macroeconomic policies can contribute towards the achievement of the sustainable development goals [9].

In the pandemic framework, with the decrease of economic activities, the labor market has faced activity limitations, and financial uncertainty has increased. Therefore, governments have found themselves forced to provide financial support to both businesses and population to avoid an economic collapse and poverty. This paper addresses the social insurance budgets in CEE countries, given the influence of fiscal policies, in general, and the socio-economic and medical characteristics of the labor market, in particular, on their sustainability. The aim of this paper is to provide empirical evidence of the influence of fiscal policies and labor market characteristics on social insurance budgets of CEE countries. We are interested in expanding research on the financing of social protection systems in CEE countries by providing some insights regarding the labor market and fiscal policies which may consolidate social insurance budget sustainability.

As mentioned before, the area of interest of this paper is the sustainability of social insurance budgets in Central and Eastern European countries and the research focus is the influence of fiscal policies and labor market characteristics on sustainable social insurance budgets. This influence derives from the specific functioning principles of social protection systems of these countries: the social contribution of employees and employers become revenues of social insurance budgets, which are used for the allocation of the provision for the beneficiaries, resulting in expenditures of social insurance budgets. Therefore, there are two main factors which affect the revenues of social insurance budgets: fiscal policies regarding the social contribution rate and labor market features such as employment, unemployment, human capital.

The paper is organized in five sections. The first part introduces the main aspects regarding public social protection systems and the objective of this research. The next section is dedicated to an analysis of the literature regarding social protection systems and the correlation with labor market and fiscal policies, the research questions and hypothesis being stated. The following sections are dedicated to presenting the research methodology and the results obtained. In the last section, the conclusions of the paper are drawn, and the implications of fiscal and social policies are emphasized, as well as this research limitations and some further directions.

\section{Literature Review and Hypotheses}

Social insurance budgets provide long-term sustainability and stability of economies in the European Union. The organization and functioning of social protection systems in Europe were studied by Esping-Andersen [10], Sapir [11], Flores [12] and Orosz [13], who noted similarities depending on the geographical area, socio-cultural and economic system, and ideology of the governing system (Table 1). Central and Eastern Europe (CEE) has a conservative typology of social protection systems, based on state interventionism and the principles promoted by Chancellor Otto von Bismarck, namely, social solidarity, contribution, and intergenerational redistribution. As a result, the demographic characteristics and the structure of the labor market are the key factors that determine the way they function. 
Table 1. Typology of social protection systems.

\begin{tabular}{|c|c|c|c|}
\hline Author & $\begin{array}{l}\text { Typology of Social } \\
\text { Protection Systems }\end{array}$ & Main Features & Representative Countries \\
\hline \multirow{3}{*}{ Esping-Andersen [10] } & Liberal & $\begin{array}{ll}\text { - } & \text { independence and } \\
\text { individual responsibility } \\
\text { - } \quad \text { minimum state intervention }\end{array}$ & Great Britain, Ireland \\
\hline & Conservative-corporate & $\begin{array}{ll}\text { - } & \text { social solidarity } \\
\text { - } & \text { the redistributive role of the state }\end{array}$ & $\begin{array}{c}\text { France, Belgium, } \\
\text { Germany, Italy, Austria }\end{array}$ \\
\hline & Socio-democratic & $\begin{array}{ll}\text { - } & \text { mutual responsibility of the citizens } \\
\text { - } & \text { equality and social equity }\end{array}$ & Sweden, Norway, Denmark \\
\hline \multirow{4}{*}{ Sapir [11] } & Anglo-Saxon & $\begin{array}{ll}- & \text { individual responsibility } \\
\text { - } & \text { state intervention as last resort }\end{array}$ & Great Britain, Ireland \\
\hline & Northern & $\begin{array}{ll}- & \text { universal benefits } \\
\text { - } & \text { equity and equality }\end{array}$ & Sweden, Norway \\
\hline & Continental & labor contribution & France, Germany \\
\hline & Mediterranean & $\begin{array}{ll}\text { - } & \text { ability to pay } \\
\text { - } & \text { powerful conditioning in } \\
\text { accessing benefits }\end{array}$ & Italy \\
\hline Flores [12]; Orosz [13] & In transition & $\begin{array}{l}\text { - } \quad \text { socialist influence } \\
\text { - } \quad \text { reforming and adapting to the new } \\
\text { socio-economic conditions }\end{array}$ & CEE \\
\hline
\end{tabular}

The abolition of the socialist system of government, the transition to a democratic system, the liberalization of markets, the integration in the European Union along with the adoption of its values have had a major impact on the CEE countries. Social protection systems faced a mismatch between taxpayers and beneficiaries and between revenues and expenditures with provided benefits, requiring a reform to reflect the new socio-economic conditions. Thus, the CEE countries present a typology of social protection systems in transition, being "inherited" from the period of socialist government and carrying out multiple reforms to adapt to the new demographic and socio-economic reality.

The public social protection systems are financed from compulsory salary withdrawals, related to the contributory capacity and conditioned by the level of salary incomes. As a result, an important question arises for the purpose of the research: "Are wage income and the level of the social contribution rate the main factors that determine the revenues of state social insurance budgets in CEE countries?"

The current demographic context characteristic of CEE countries reflects on one hand the aging population and, on the other hand, the relocation of the young population to more socio-economically developed areas. Population aging is the cumulative effect of reducing birth rates and increasing life expectancy, the main cause being scientific and technological progress, economic development, access to education, and strengthening respect for people's rights to social protection [14,15].

Free movement of the population is a fundamental right of the EU, with multiple implications: from attracting foreign investment, economic growth, and capital market development to shifting economic activities, avoiding taxation, and eroding the tax base, international double taxation, thus restricting the right to social protection [16-19].

From a fiscal point of view, emigration of the labor force decreases the income tax and social contributions revenues and, as a consequence, the labor taxation must be increased to ensure the financing of state spending [20]. The fiscal policies nationally adopted play an important role in this regard. In terms of social protection systems, an aging population will require a higher spending with social protection benefits, especially with 
pensions and health care services [21]. Vučković and Škuflić showed similar results in their study regarding the Baltic and CEE countries situation, highlighting that emigration has a negative influence on the sustainability of social protection budgets [22].

The Covid-19 pandemics has limited the economic activities and led to a reorganization of the labor market, with expected effects such as the reduction of trade, rising unemployment, causing budget deficits, and increasing public debt [23]. Albu et al. estimated a decrease of the global GDP in 2020 up to $14.6 \%$ and in the EU between $7.4 \%$ and $9.3 \%$, while in Romania, the GDP reduction could be between $5 \%$ and $7.9 \%$ [24]. In order to cope with the effects of the current pandemic, governments and EU institutions implemented a socio-economic recovery plan including joint debt issuance and a policy of intra-state financial redistribution, indirect redistribution across states, direct economic support to the most affected states and regions, fiscal prudence, and deficit spending [25]. However, according to O'Donoghue et al., despite the increased social benefits and the decline in tax rate, income inequality has continued to rise during the COVID crisis, suggesting the need for improving income-support policies [26].

In these conditions of uncertainty, this paper addresses the social insurance budgets in CEE countries, given the influence of fiscal policies and socio-economic and medical characteristics of the labor market on their sustainability. Considering that the financing mechanism of social protection systems is based on compulsory salary withdrawals from the employed population, social insurance budgets are directly influenced by the labor market employment rate. Nowadays, due to the COVID-19 pandemic, companies all over the world have faced a temporary suspended activity or even had to close, increasing the unemployment rate [27], and, as a consequence, a reduction of revenues of social insurance budgets is expected.

The larger part of the revenues of the public sector is accumulated from taxes and social contributions. Authors like Aronsson and Micheletto, Omran and Bilan, Libanova et al. showed that employment and unemployment policies impact the tax revenues and the public budget receipts [28-30]. Moreover, several studies introduced the importance of human capital, their skills and knowledge to promote economic and social development, labor market competitiveness, social security, welfare and national budget's revenues [31-34]. Therefore, the following research hypotheses were established:

Hypothesis 1 (H1). Increasing the employment rate and reducing the unemployment rate will lead to an increase in social insurance budget revenues from social contributions in CEE countries.

Hypothesis 2 (H2). The level of the human development index influences the revenues of state social insurance budgets from social contributions in CEE countries with effects on sustainable development.

Fighting COVID-19 has become the priority for many social protection and health systems and may interfere with the achievement of sustainable development goals [35]; however, these goals are contributing to the alleviation of the pandemic effects in a globalized world and must be pursued [36]. A key item is fiscal balance, which can positively influence the growth rate [37] and support the recovery from the pandemic. Nevertheless, fiscal improvement seems to lead to economic growth [38].

\section{Materials and Methods}

The purpose of this article is to highlight the influence of adopted fiscal policies and labor market characteristics on sustainable social insurance budgets in six CEE countries, i.e., the Czech Republic, Hungary, Poland, Romania, Bulgaria, and Slovakia. In this empirical part of the paper, correlations between the social contribution revenues of social insurance budgets and socio-economic and medical indicators of labor market were investigated. As a result, a database was built on the basis of data published by Eurostat and the United Nations for the period 2008-2018, the indicators considered relevant for the purpose of the research being: 
1. financing source of social insurance budgets: revenues collected from social contributions (SPR_SC);

2. socio-economic characteristics of the labor market: employment rate (ER), unemployment rate (UR), human development index (HDI), average gross wage (AGW), share of social contributions (SCQ);

3. socio-medical characteristics of the labor market: duration of the working life (DWL), healthy life expectancy (HLY), working accidents (WA).

Social insurance budget revenues obtained from social contributions are defined as the total level of revenues collected from financial levies, in the form of compulsory social contributions applied to the gross income, borne by persons employed in the labor market, as a percentage of GDP.

The revenues of the budgets of public social insurance systems were obtained from two main sources, namely, the mandatory social contributions and the government transfers (Figure 1). In the period 2008-2018, income from social contributions paid by employers, employees, self-employed persons, and other insured persons represented over $70 \%$ of total income in the Czech Republic and a share between 50\% and 70\% of total income in other CEE countries. The highest share of income from social contributions in the period 2000-2018 was held by social contributions paid by employers (up to 50\% of income), except for Romania in 2018, where the share of income obtained from social contributions paid by employees exceeded $60 \%$ of the total budget revenues.

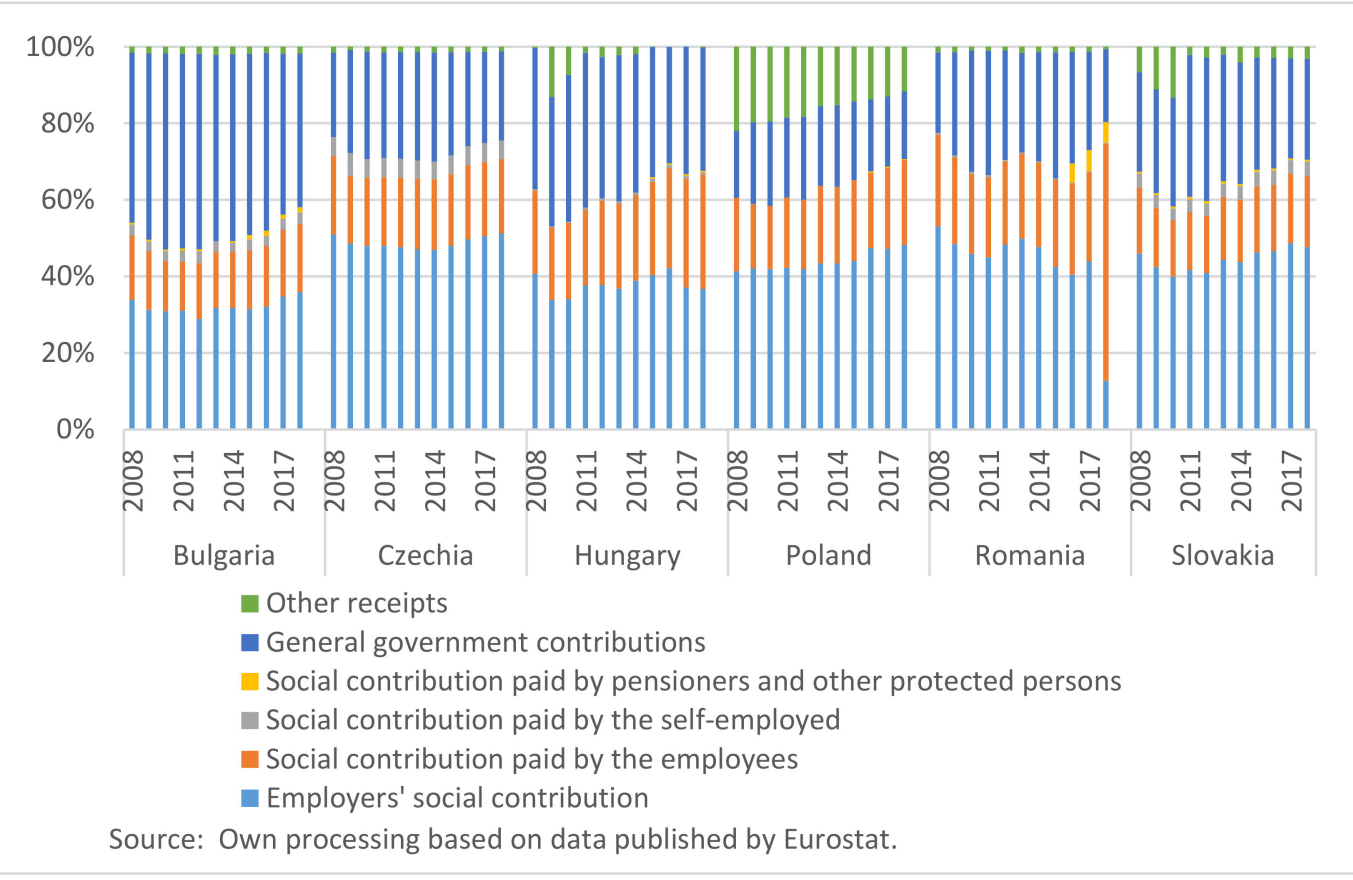

Figure 1. Structure of the revenues of public social insurance system.

The employment rate represents the percentage of people who perform a paid activity or who are temporarily on leave, in the total population, having the capacity to carry out professional activities. The unemployment rate shows the percentage of people aged between 15 and 74 who are not employed in the total workforce. The human development index measures the main characteristics of the population and their ability to ensure the development of a country. Between 2008 and 2018, the employment rate increased by 12.8\% in Hungary, $8.2 \%$ in the Czech Republic and Poland, 5.8\% in Romania, 5.3\% in Slovakia, and $3.7 \%$ in Bulgaria (Figure 2). At the same time, the unemployment rate decreased by 4.1\% in Hungary, 3.2\% in Poland, 3\% in Slovakia, 2.2\% in the Czech Republic, 1.6\% in Romania, and only $0.4 \%$ in Bulgaria. Regarding the HDI, the level of the index increased in 
all six European countries. The highest increase was registered in Bulgaria $(+0.045)$, Czech Republic (+0.037), and Slovakia (+0.035), followed by Hungary (+2.7), Poland (+2.6), and Romania (+0.021).

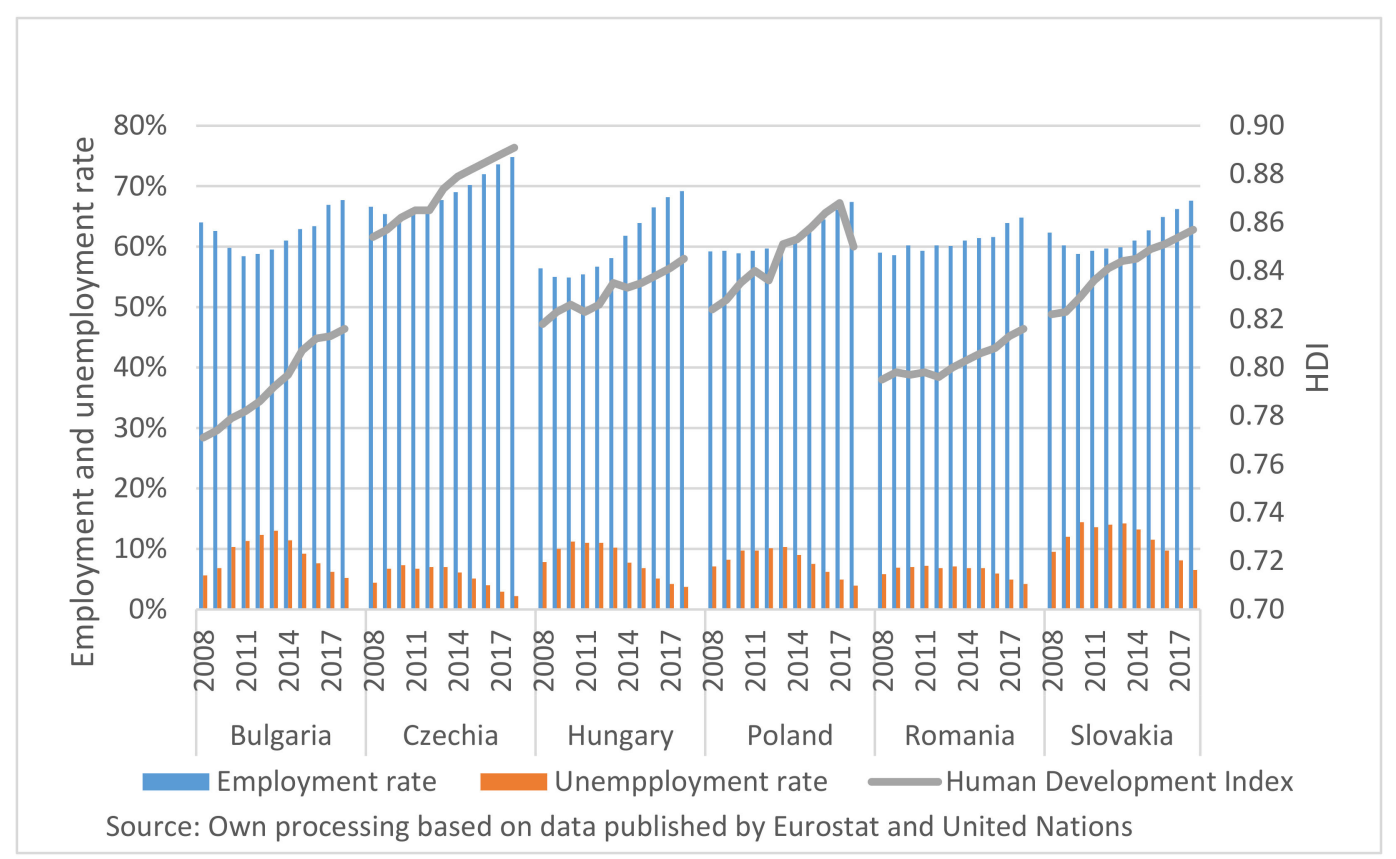

Figure 2. Employment rate, unemployment rate, and HDI.

The average gross wage expresses the average annual level of remuneration and other payments received by an unmarried person without children, before withholding taxes, fees, and compulsory social contributions. In CEE countries, the level of the average wage increased in the period 2008-2018, the highest increase being registered in Bulgaria $(+117 \%)$ and Romania (+94\%), while in the other countries, the increase was between $34 \%$ and $40 \%$ (Figure 3). However, in monetary terms, the incomes achieved by Bulgarian and Romanian employees were lower, compared to those obtained by employees in the other CEE countries. Social contributions represent a mandatory pecuniary levy that individuals and/or legal entities pay from their income to the social insurance budget. The level of compulsory social contributions in all five European countries rose to over $35 \%$.

The duration of working life is defined as the number of years that a person is supposed to be active in the labor market, and healthy life expectancy shows the number of years that a person expects to live without major or severe health problems. The duration of working life of the population of the five CEE countries increased between 2008 and 2018 to values of over 30 years, the highest increase being 5.4 years in Hungary. In addition, healthy life expectancy increased to values between 53 and 65 years. However, in Romania, healthy life expectancy decreased by 2.1 years (Figure 4 ).

Accidents at work are defined as physical or mental injuries occurred during the performance of a professional activity or during the period spent at work. In the CEE countries, in recent years, there has been a tendency to reduction of accidents at work, especially of those with a high degree of severity and fatal (Figure 5).

Data processing and econometric tests were employed using the software package EViews 10. Our empirical research on the influence of fiscal policies and labor market characteristics on sustainable social insurance budgets in Central and Eastern European countries was a panel study based on a regression model, which considered the budget revenues from social contributions as a dependent variable, and employment rate, unemployment rate, human development index, average wage income, share of social contributions as independent variables. The control variables used were duration of working 
life, healthy life expectancy, work accidents. A dummy variable was also included, the implementation of a second pillar of mandatory private pension funds. The financing of mandatory private pension funds is made by the redistribution of a share of mandatory contributions of taxpayers; therefore, the social insurance budged is deprived of revenues. In CEE countries, the second pillar is functioning only in Bulgaria, Romania, and Slovakia.

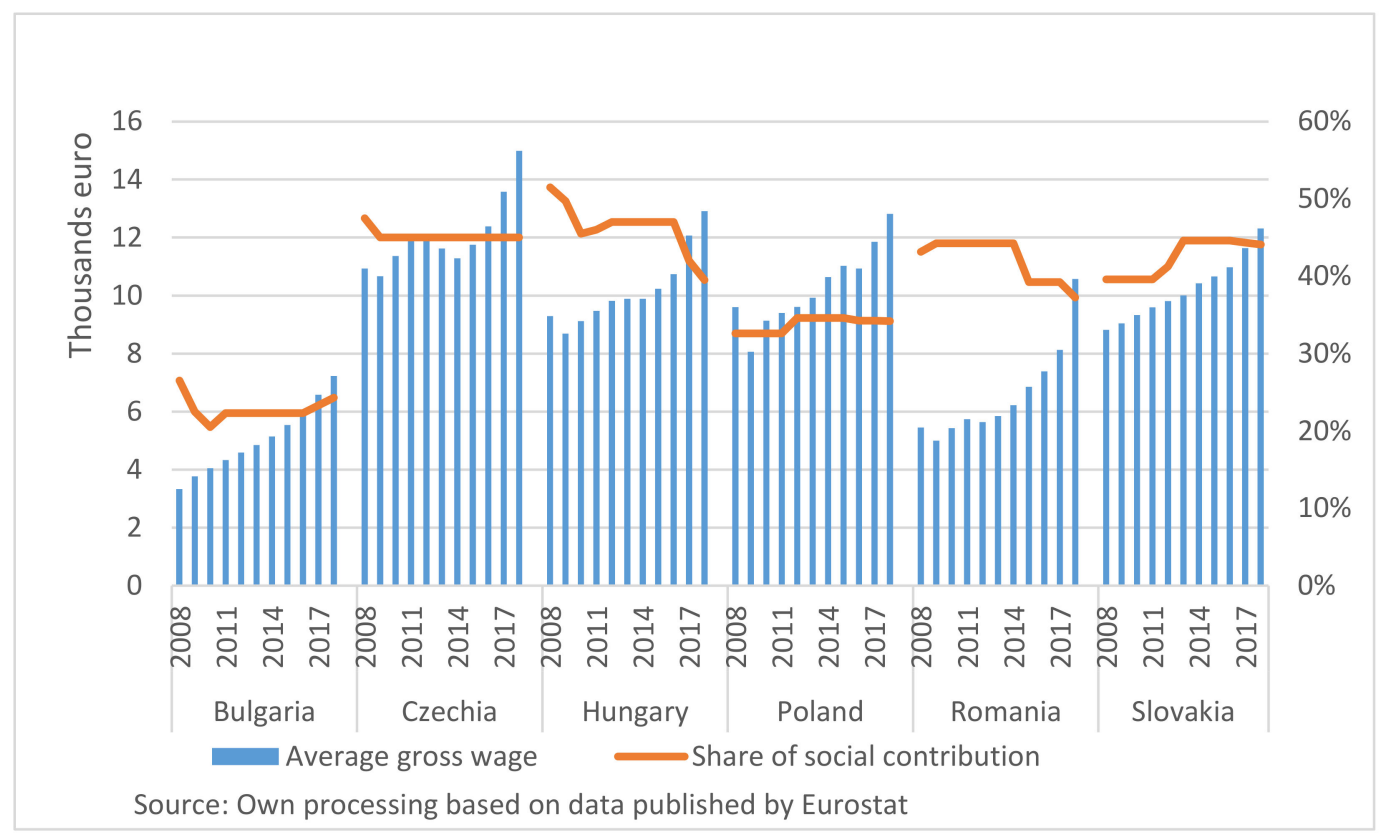

Figure 3. Average annual gross wage and share of compulsory social contributions.

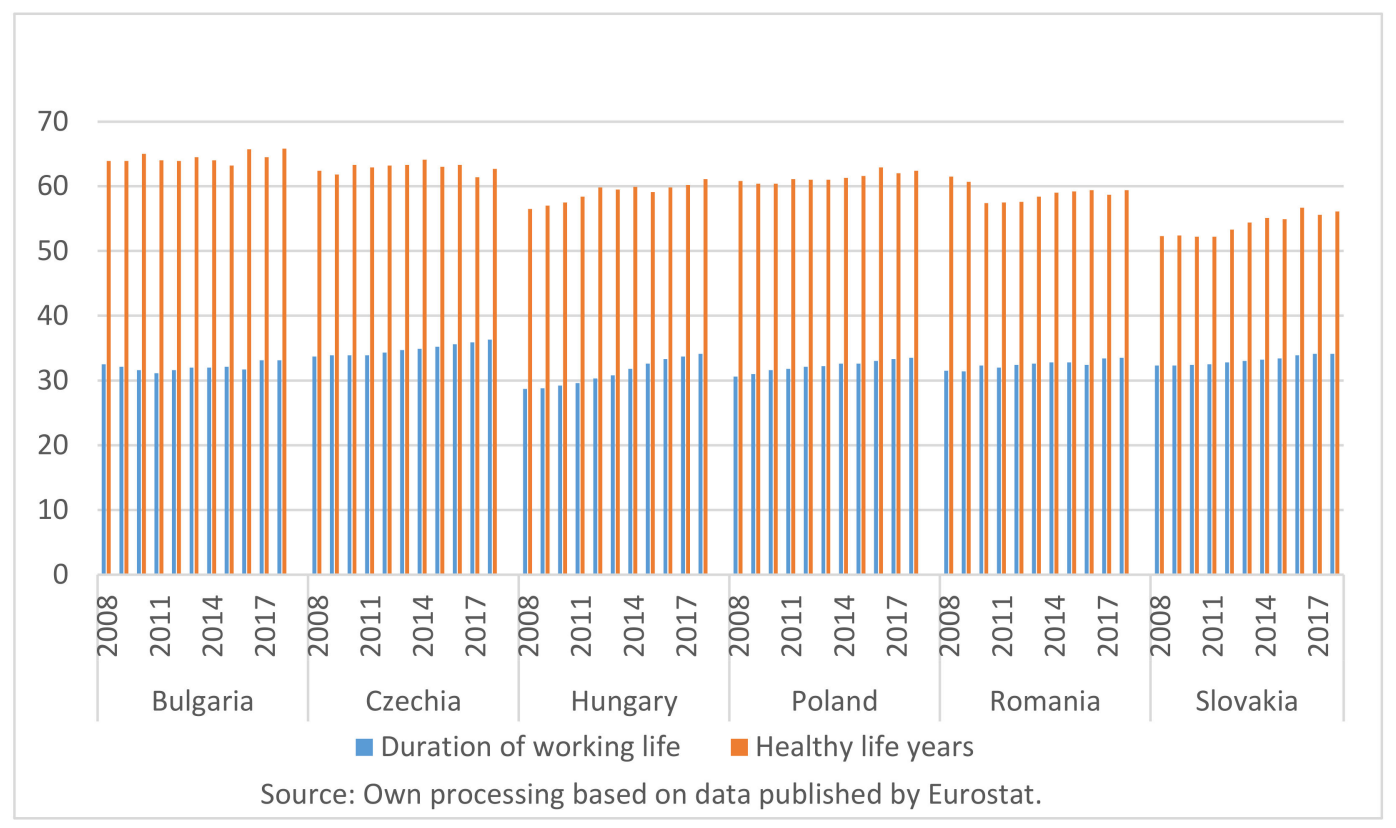

Figure 4. Duration of working life and heathy life years in CEE countries. 


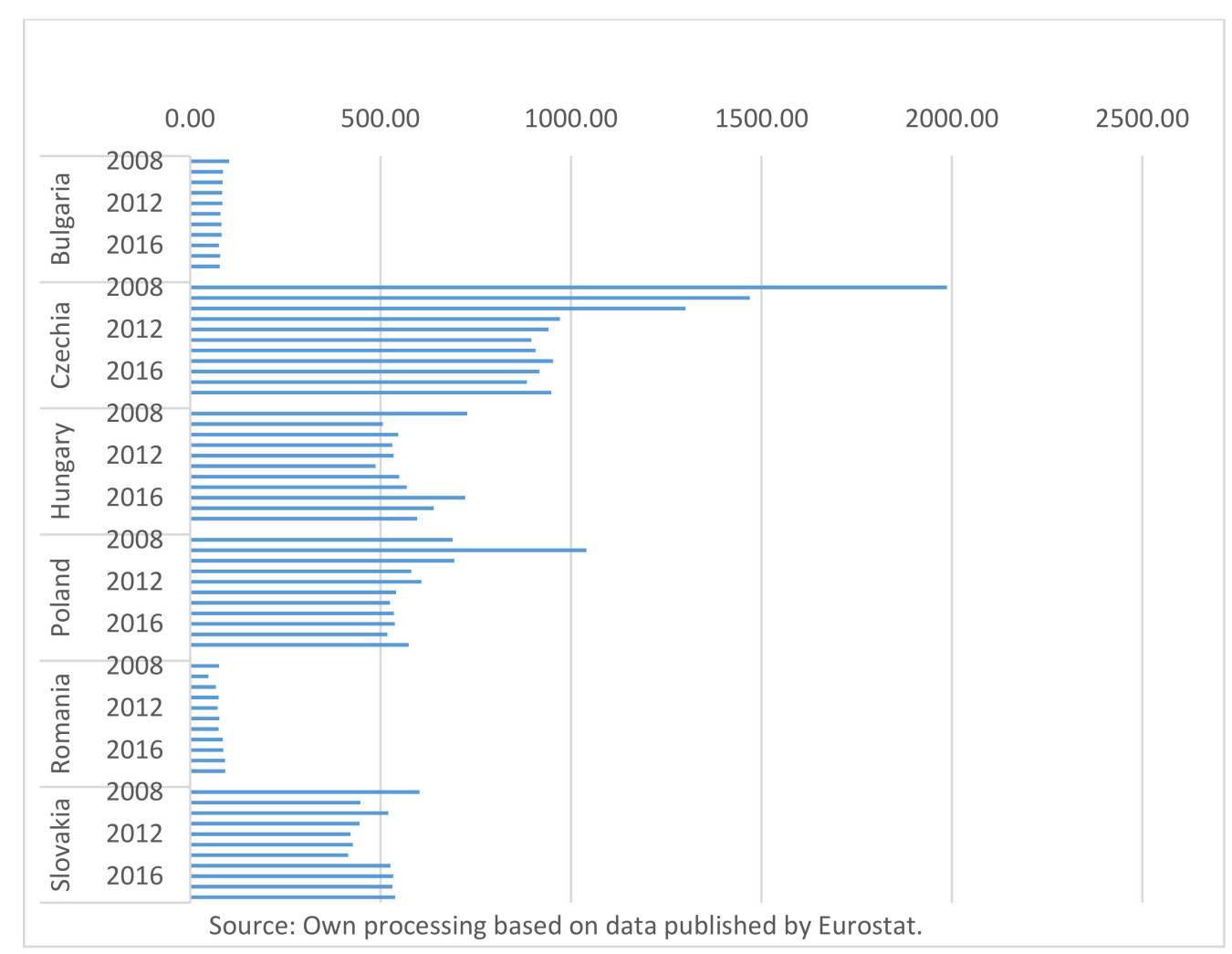

Figure 5. Accidents at work in CEE countries.

The research method used to determine the correlations between funding sources and labor market specific indicators was the Ordinary Least Squares (OLS), with cross section random effects, assuming that there is an independent random variable that explains the variance between $\mathrm{CEE}$ countries. The regression equation used is presented below:

$S P R \_S C_{i t}=\alpha+\beta_{1} x E R_{i t}+\beta_{2} x U R_{i t}+\beta_{3} x H D I_{i t}+\beta_{4} x A G W_{i t}+\beta_{5} x S C Q_{i t}+\beta_{6} x D W L_{i t}+\beta_{7} x H L Y_{i t}+\beta_{8} x W A_{i t}+\varepsilon_{i t}$

where:

$\alpha$-free coefficient

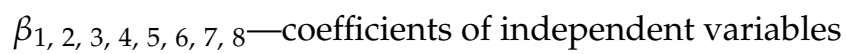

$S P R \_S C$ - budget revenues from social contributions

$E R$-employment rate

UR-unemployment rate

HDI-human development index

$A G W$-average gross wage per year

$S C Q$ - share of social contributions

DWL-duration of working life

$H L Y$ - healthy life expectancy

WA-work accidents

\section{Results and Discussion}

The descriptive statistics of the variables mentioned above reflect, through the JarqueBera test, the normal distribution of mandatory social contributions, healthy life expectancy, and accidents at work, the other variables having an abnormal distribution. There is a positive asymmetry of employment rate, unemployment rate, and working accidents, all the other variables having a negative asymmetry. The Kurtosis coefficient reflects the leptokurtic distribution of duration of working life and working accidents and the platykurtic distribution of the other variables (Table 2). 
Table 2. Descriptive statistics of the variables.

\begin{tabular}{cccccc}
\hline & Mean & Median & Maximum & Minimum & Std. Dev. \\
\hline SPR_SC & 11.95455 & 12.2 & 15.1 & 8.3 & 1.839079 \\
\hline ER & 62.71667 & 61.75 & 74.8 & 54.9 & 4.393057 \\
\hline UR & 8.025758 & 7.15 & 14.4 & 2.2 & 2.975609 \\
\hline HDI & 0.831242 & 0.834 & 0.891 & 0.771 & 0.029443 \\
\hline AGW & 9059.74 & 9603.075 & $14,984.75$ & 3328.05 & 2754.822 \\
\hline SCQ & 38.7753 & 42.575 & 51.5 & 20.5 & 8.5122 \\
\hline DWL & 32.62879 & 32.6 & 36.3 & 28.7 & 1.527569 \\
\hline HLY & 60.11364 & 60.75 & 65.8 & 52.2 & 3.533701 \\
\hline WA & 494.0083 & 528.39 & 1987.06 & 47.93 & 386.5009 \\
\hline SPR_SC & \multicolumn{2}{c}{ Skewness } & Kurtosis & Jarque-Bera & Probability \\
\hline ER & -0.22176 & 2.133158 & 2.607332 & 0.271534 \\
\hline UR & 0.569601 & 2.94567 & 3.577017 & 0.167209 \\
\hline HDI & 0.37203 & 2.378647 & 2.584187 & 0.274695 \\
\hline AGW & -0.00516 & 2.314791 & 1.291448 & 0.524283 \\
\hline SCQ & -0.35814 & 2.223116 & 3.070643 & 0.215386 \\
\hline DWL & -0.88529 & 2.550803 & 9.175907 & 0.010174 \\
\hline HLY & -0.23139 & 3.60206 & 1.585759 & 0.45254 \\
\hline WA & -0.62658 & 2.651258 & 4.653139 & 0.09763 \\
\hline
\end{tabular}

The aim of our study was to analyze the influence of labor market characteristics on social insurance budgets in CEE countries based on social contributions using the regression Equation (1). We performed tests to identify the multi-collinearity of the variables. The corresponding correlation matrix is presented in Table 3. We did not consider in the same regression the variables correlated at a higher level than 0.5 , because, otherwise, bias coefficients of the independent variables can be obtained in the regression models of the research.

Table 3. Correlation matrix of the independent variables.

\begin{tabular}{ccccccccc}
\hline & ER & UE & HDI & AGW & SCQ & DWL & HLY & WA \\
\hline ER & 1.00 & & & & & & & \\
\hline UE & -0.71 & 1.00 & & & & & & \\
\hline HDI & 0.61 & -0.26 & 1.00 & & & & & \\
\hline AGW & 0.56 & -0.28 & 0.94 & 1.00 & & & & \\
\hline SCQ & 0.08 & -0.15 & 0.49 & 0.56 & 1.00 & & & \\
\hline DWL & 0.91 & -0.50 & 0.62 & 0.53 & 0.15 & 1.00 & & \\
\hline HLY & 0.36 & -0.46 & -0.02 & -0.16 & -0.51 & 0.18 & 1.00 & \\
\hline WA & 0.39 & -0.22 & 0.75 & 0.72 & 0.47 & 0.35 & 0.04 & 1.00 \\
\hline
\end{tabular}

The results of the panel data model are presented in Table 4 .

According to our model, a positive correlation is established between the level of budgetary revenues obtained from social contributions and the human development index (HDI), the average gross wage (AGW), the share of compulsory social contributions (SCQ), the employment rate (ER), and the working accidents (WA). Income from social 
contributions appeared to be negatively correlated with the rate of unemployment (UE), duration of working life (DWL) and healthy life expectancy (HLY).

Table 4. Empiric results.

\begin{tabular}{cccc}
\hline Variable & $\mathbf{( 1 )}$ & $\mathbf{( 2 )}$ & $\mathbf{( 3 )}$ \\
\hline AGW & & & $0.0005^{* * *}$ \\
DWL & $-0.037^{* *}$ & $-0.33^{* * *}$ & $(7.42)$ \\
HDI & $(-2.81)$ & $(-4.75)$ & \\
HLY & & $\left(10.48^{* * *}\right.$ & \\
& & & $-0.15^{*}$ \\
Second Pillar & & & $(-1.41)$ \\
SCQ & & & $-1.13^{* * *}$ \\
& $0.10^{* * *}$ & $0.05^{* * *}$ & $(-2.23)$ \\
UR & $(9.01)$ & $(5.79)$ & \\
ER & & $-0.08 * * *$ & -0.03 \\
WA & $0.20^{* * *}$ & $(-2.86)$ & $(-0.73)$ \\
INTERCEPT & $(4.22)$ & & \\
R-squared & $0.002^{* * *}$ & 0.001 & \\
\hline Not & $(7.92)$ & $(1.60)$ & $15.37^{* * * *}$ \\
& $6.42^{* * *}$ & $-20.61^{* * *}$ & $(3.51)$ \\
& $(2.25)$ & $(-6.76)$ & $79.20 \%$ \\
\hline
\end{tabular}

Note: ${ }^{*}$ statistical significance at $10 \%,{ }^{* *}$ statistical significance at $5 \%,{ }^{* * *}$ statistical significance at $1 \%$.

The empirical results obtained reflect the positive correlation between income from social contributions and the employment rate. As expected, the increase of employment rate in CEE countries would increase the income from social contributions. Regarding the unemployment rate, this is a significant factor in determining the budget revenues from social contributions, the results obtained showing that budget revenues from social contributions may increase with the reduction of the unemployment rate.

The human development index is a significant factor in determining the budget revenues from social contributions. The results showed that increasing the human development index would increase the budget revenues from social contributions.

The research hypothesis was confirmed, indicating that employment, unemployment, and human development index influence the social protection budgets of CEE countries. These results are consistent with the results obtained by Hossain and Rahaman, which showed that unemployment and change of human quality index have negative impacts on the economic growth, especially in a crisis situation [39]. In addition, Bulbaet al. emphasized that the effectiveness and sustainability of social programs can be achieved only by increasing the investment in human capital [40].

The average wage and the share of social contributions are indeed significant factors in determining the budget revenues from social contributions. The results obtained reflect the fact that the increase of the population's income and the increase of the share of social contributions will lead to the increase of the budgetary income from social contributions. As expected, the results confirm the dependence between social insurance budget revenues and the level of population incomes.

Similar results were obtained by other authors $[41,42]$ that highlighted the importance of personal income taxes to public budgets and other government policies such as economic development, country's competitiveness, and sustainable growth. However, there are studies that showed that the increase of the social contribution rate can lead to a decline in labor participation and jeopardize budget revenues and fiscal sustainability [43].

The second pillar of the pension system is also a significant variable in the determination of social insurance budget revenues supplied from social contribution. A negative 
correlation was established between social insurance revenues and the functioning of mandatory private pension funds, given their financing from the social contributions paid by taxpayers. One reason for canceling the mandatory private pension funds in Hungary and Poland was precisely the reduction of revenues and the deficit of social insurance budget $[44,45]$. Balazs noted that this policy had a positive effect on the sustainability of Poland's pension budget [46], but Carp highlighted the inadequacy of this policy for the purpose of pension systems, considering that it will not ensure long-term sustainability [47].

Control variables have a different influence on the dependent variable. Thus, the results obtained showed that the duration of working life is a significant factor influencing budget revenues and that a longer active period does not increase the revenues from social contributions. Our results are consistent with other studies that concluded that a longer working life does not increase the employment rate and neither has a significant effect on the social protection system sustainability $[48,49]$. On the contrary, a longer working life can induce an increase in unemployment, as was also shown by Jimon et al. [50].

Healthy life expectancy also has a negative influence on budget revenues from social contributions, the results suggesting that consolidating the life expectancy with health will not lead to an increase in budget revenues from social contributions. With regard to accidents at work, a positive correlation between working accidents and budget revenues from social contributions was established.

The empirical results of our study show that labor market characteristics and fiscal policy influence the social insurance budgets in CEE countries. However, according to other authors, the sustainability of social protection systems cannot be guaranteed only by the enlargement of the social contributions collection base, a sustainable growth of the entire national economy being necessary [51].

\section{Conclusions}

National budget revenues and the fiscal policies adopted have an important role in the achievement of sustainable development goals in an economy. As already observed in the research done, the complexity and the interdependencies needed for facing the related changes bring all the actors playing in the field-governments, companies, employees.

The fiscal policies and the social strategies adopted by governments and their effectiveness in adding value are the subject of a contemporary debate. Social protection systems are the expression of respect for the fundamental rights of the population. Their organization and operation are carried out by the state, with the aim of reducing the financial vulnerability of citizens. In the case of the analyzed countries, their social protection systems are based on an intergenerational social solidarity and the contribution of the labor market. Labor migration and the growing share of the professionally inactive population in these countries are challenges for obtaining the resources needed for sustainable state social insurance budgets. In the European Union, the social insurance budgets are those that provide long-term sustainability and stability of an economy. We carried out this study in order to identify the influencing factors of and study the impact of fiscal policies and labor market characteristics on social insurance budgets in CEE countries in the period between 2008 and 2018. On the basis of the obtained results, we can conclude that the sustainability on a long term in CEE countries is influenced by factors such as the average level of salaries and the share of compulsory social contributions, as significant predictors. The empirical results obtained also reflect the dependence of the sustainability of social insurance budgets on the unemployment rate and the human development index.

In the current context, there is a need to ensure adequate wages, the stability of fiscal policy, the continuous professional and personal development of the workforce for sustainable economic growth, and the financing of social protection systems. The SARS-CoV-2 pandemic has increased financial uncertainty and instability, augmenting the risk of poverty and material deprivation of the population, thus emphasizing the role and importance of social protection systems. Given this context and the empirical results obtained, governments must pursue the sustainable development goals for 2030 
by implementing policies to increase the knowledge, skills, health, and well-being of human capital, as well as enhancing labor security and income soundness of workers and their families.

The limits of this article can be drawn from its objective, which limited the study of the implications of the fiscal policies and labor market characteristics on budget revenues from social contributions in Central and Eastern European countries. As a result, we believe that this research can be extended to a larger sample of countries to capture the situation specific to the different forms of organization of social protection systems. Research can also be continued by applying research methods complementary to regression analysis, as well as by taking into account other independent variables, such as the corruption index and the effectiveness of tax collection.

Author Contributions: Conceptualization, S.A.J., D.D., and A.F.P.; methodology, D.N.S. and S.A.J.; software, A.F.P. and D.N.S.; validation, D.D. and S.A.J.; formal analysis, S.A.J.; investigation, D.N.S. and D.D.; resources, A.F.P.; data curation, S.A.J.; writing-original draft preparation, D.N.S. and S.A.J.; writing-review and editing, D.N.S., A.F.P., and D.D.; visualization, D.D. and A.F.P.; supervision, D.D. and D.N.S.; project administration, A.F.P. All authors have read and agreed to the published version of the manuscript.

Funding: This research received no external funding.

Institutional Review Board Statement: Not applicable.

Informed Consent Statement: Not applicable.

Data Availability Statement: The data presented in this study are openly available in the database of Eurostat (https://ec.europa.eu/eurostat/data/database, accessed on 16 February 2021) and United Nations (http:/ / hdr.undp.org/en/content/human-development-index-hdi, accessed on 16 February 2021).

Conflicts of Interest: The authors declare no conflict of interest.

\section{References}

1. International Labour Organization. The protection of the right to Social Security in European Constitutions: Compendium of provisions of European Constitutions and Comparative tables (Online Version). Available online: http://www.ilo.org/global/ standards/subjects-covered-by-international-labour-standards/social-security/WCMS_191459/lang--en/index.htm (accessed on 19 March 2021).

2. Sabates-Wheeler, R.; Devereux, S. Transformative social protection: The currency of social justice. In Social Protection for the Poor and Poorest. Risk, Needs and Rights, Barrientos, Hulme; Palgrave Macmillan: London, UK, 2008.

3. Boadway, R.; Keen, M. Redistribution. In Handbook of Income Distribution; Atkinson, A.B., Bourguignon, F., Eds.; Elsevier: Amsterdam, The Netherlands, 2000.

4. Anderson, C.J.; Pontusson, J. Workers, worries and welfare states: Social protection and job insecurity in 15 OECD countries. Eur. J. Political Res. 2007, 46, 211-235. [CrossRef]

5. Sverke, M.; Låstad, L.; Hellgren, J.; Richter, A.; Näswall, K. A Meta-Analysis of Job Insecurity and Employee Performance: Testing Temporal Aspects, Rating Source, Welfare Regime, and Union Density as Moderators. Int. J. Environ. Res. Public Health 2019, 16, 2536. [CrossRef] [PubMed]

6. Cortès-Franch, I.; Puig-Barrachina, V.; Vargas-Leguás, H.; Arcas, M.; Artazcoz, L. Is Being Employed Always Better for Mental Wellbeing Than Being Unemployed? Exploring the Role of Gender and Welfare State Regimes during the Economic Crisis. Int. J. Environ. Res. Public Health 2019, 16, 4799. [CrossRef]

7. Iparraguirre, J.L. Economics and Ageing-Volume III: Long-Term Care and Finance; Palgrave Macmillan: London, UK, 2020.

8. Hansmann, R.; Mieg, H.A.; Frischknecht, P. Principal sustainability components: Empirical analysis of synergies between the three pillars of sustainability. Int. J. Sustain. Dev. World Ecol. 2012, 19, 451-459. [CrossRef]

9. United Nations Conference on Trade and Development. How Labour and Macroeconomic Policies Can Contribute towards the Achievement of the Sustainable Development Goals? Available online: https:/ / unctad.org/system/files/official-document/ cimem8d8_en.pdf (accessed on 19 March 2021).

10. Esping-Andersen, G. The Three Worlds of Welfare Capitalism; Princeton University Press: Princeton, NJ, USA, 2019.

11. Sapir, A. Globalisation and the reform of European social models. J. Common Mark. Stud. 2006, 44, 369-390. [CrossRef]

12. Flores, M.F. Essays on Early Life Circumstances, Health and Labor Market Outcomes in Europe. Ph.D. Thesis, Instituto Universitario de Estudos e Desenvolvemento de Galicia (IDEGA), Santiago de Compostela, Spain, 2014.

13. Orosz, A. The Emergence of East Central Europe in a Welfare Regime Typology. Bord. Crossing 2019, 9, 97-112. [CrossRef] 
14. Bricker, D.; Ibbitson, J. Empty Planet: The Shock of Global Population Decline; Crown Publishers: New York, NY, USA, 2009.

15. Pradhan, E. Female Education and Childbearing: A Closer Look at the Data. In Investing in Health. Available online: https: / / blogs.worldbank.org/health/female-education-and-childbearing-closer-look-data (accessed on 17 March 2021).

16. Simionescu, M. What Drives Economic Growth in some CEE Countries? Studia Univ. Vasile Goldis Arad Econ. Ser. 2018, 28, 46-56. [CrossRef]

17. Precup, M. The Economic Growth and the Opportunity for the Private Equity Funds to Divest: An Empirical Analysis for Eastern Europe. Studia Univ. Vasile Goldis Arad Econ. Ser. 2019, 29, 1-19. [CrossRef]

18. Dumiter, F.C.; Jimon, S.A. Theoretical and Practical Assessments of Transfer Prices. Legal Evidence from Romanian Case Law. J. Leg. Stud. 2020, 26, 1-18. [CrossRef]

19. Holzmann, R.; Koettl, J. Stability of Pension, Health, and other Social Benefits: Facts, Concepts, and Issues. CESifo Econ. Stud. 2015, 61, 377-415. [CrossRef]

20. Atoyan, R.; Christiansen, L.; Dizioli, A.; Ebeke, C.; Ilahi, N.; Ilyina, A.; Mehrez, G.; Qu, H.; Raei, F.; Rhee, A.; et al. Emigration and Its Economic Impact on Eastern Europe. IMF Staff Discussion Note SDN/16/07. Available online: https://www.imf.org/external/ pubs/ft/sdn/2016/sdn1607.pdf (accessed on 17 March 2021).

21. Clements, B.; Dybczak, K.; Gaspar, V.; Gupta, S.; Soto, M. The Fiscal Consequences of Shrinking Populations, in IMF Staff Discussion Note SDN/15/2. Available online: https://www.imf.org/external/pubs/ft/sdn/2015/sdn1521.pdf (accessed on 17 March 2021).

22. Vučković, V.; Škuflić, L. The effect of emigration on financial and social pension system sustainability in EU new member states: Panel data analysis. Econ. Sociol. 2021, 14, 145-158. [CrossRef]

23. European Commission European. Economic Forecast-Spring 2020. Available online: https://ec.europa.eu/info/publications/ european-economic-forecast-spring-2020_en (accessed on 17 March 2021).

24. Albu, L.L.; Preda, C.I.; Lupu, R.; Dobrotă, C.E.; Călin, G.M.; Boghicevici, C.M. Estimates of dynamics of the COVID19 pandemic and of its impact on the economy. Rom. J. Econ. Forecast. 2020, 23, 5-17.

25. Ladi, S.; Tsarouhas, D. EU economic governance and Covid-19: Policy learning and windows of opportunity. J. Eur. Integr. 2020, 42, 1041-1056. [CrossRef]

26. O'Donoghue, C.; Sologon, D.M.; Kyzyma, I.; McHale, J. Modelling the distributional impact of the COVID-19 crisis. Fisc. Stud. 2020, 41, 321-336. [CrossRef]

27. McCloskey, B.; Zumla, A.; Ippolito, G.; Blumberg, L.; Arbon, P.; Cicero, A.; Endericks, T.; Lim, P.L.; Borodina, M. Mass gathering events and reducing further global spread of COVID-19: A political and public health dilemma. Lancet 2020, 395, 1096-1099. [CrossRef]

28. Aronsson, T.; Micheletto, L. Optimal Redistributive Income Taxation and Efficiency Wages. Scand. J. Econ. 2021, 123, 3-32. [CrossRef]

29. Libanova, E.M.; Makarova, O.V.; Sarioglo, V.G. Activation Policy as an Investment in Human Capital: Theory and Practice. Sci. Innov. 2020, 16, 52-62. [CrossRef]

30. Omran, E.A.M.; Bilan, Y. The Impact of Fiscal Policy on the Unemployment Rate in Egypt. Montenegrin J. Econ. 2020, 16, 199-209. [CrossRef]

31. Toth, A.; Juhasz, T.; Kalman, B. The Role of Innovation and Human Factor in the Development of East Central Europe. Montenegrin J. Econ. 2020, 16, 251-274. [CrossRef]

32. Csath, M. Competitiveness Based on Knowledge and Innovation. Public Financ. Q. Hung. 2018, 63, 64-79.

33. Reis, C. Optimal taxation with unobservable investment in human capital. Oxf. Econ. Pap. 2020, 72, 501-516. [CrossRef]

34. Caliendo, F.N.; Findley, T.S. Myopia, education, and social security. Int. Tax Public Financ. 2020, 27, 694-720. [CrossRef]

35. Leal, F.W.; Brandli, L.L.; Lange, S.A.; Rayman-Bacchus, L.; Platje, J. COVID-19 and the UN sustainable development goals: Threat to solidarity or an opportunity? Sustainability 2020, 12, 5343. [CrossRef]

36. Hörisch, J. The relation of COVID-19 to the UN sustainable development goals: Implications for sustainability accounting, management and policy research. Sustain. Account. Manag. Policy J. 2020, 2040-8021. [CrossRef]

37. Liargovas, P.; Psychalis, M.; Apostolopoulos, N. Fiscal policy, growth and entrepreneurship in the EMU. Eur. Politics Soc. 2021, 1-22. [CrossRef]

38. Apostolopoulos, N.; Psychalis, M.; Liargovas, P.; Pistikou, V. Investigating Government lending during an economic crisis: A comparative analysis of four EU countries. Eur. Politics Soc. 2021, 1-15. [CrossRef]

39. Hossain, S.; Rahaman, M. The Post COVID-19 Global Economy: An Econometric Analysis. IOSR J. Econ. Financ. 2021, 12, 22-43.

40. Bulba, V.G.; Goncharenko, M.V.; Yevtuxov, O.V. Fiscal mechanism in public administration of social risks. Cuest. Politicas 2021, 39, 531-548. [CrossRef]

41. Szarowska, I. Personal income taxation in a context of a tax structure. Procedia Econ. Financ. 2014, 12, 662-669. [CrossRef]

42. Tikhonova, A.; Goncharenko, L.; Melnikova, N.; Malkova, Y. An Assessment of the Influence of the Current National Economy Development State upon Personal Income Taxation System. In Proceedings of the Vision 2020: Sustainable Economic Development and Application of Innovation Management, 32nd Conference of the International-Business-Information-ManagementAssociation (IBIMA), Seville, Spain, 15-16 November 2018; Soliman. pp. 7982-7989.

43. Belev, S.G.; Moguchev, N.S.; Vekerle, K.V. Fiscal Effects of Labour Income Tax Changes in Russia. J. Tax Reform 2020, 6, 210-224. [CrossRef] 
44. Szikra, D. Reversing Privatization and Re-Nationalizing Pensions in Hungary. ESS-Working Paper No. 66, Social Protection Department. Available online: https:/ / www.social-protection.org/gimi/RessourcePDF.action?id=55307 (accessed on 16 March 2021).

45. OECD. Pension Markets in Focus. Available online: https://www.oecd.org/finance/private-pensions / pensionmarketsinfocus. htm (accessed on 16 March 2021).

46. Balazs, E. The impact of changes in second pension pillars on public finances in Central and Eastern Europe: The case of Poland. Econ. Syst. 2013, 37, 473-491.

47. Carp, A. Scenarii privind evoluţia sistemului de pensii private din România. Rom. Stat. Rev. 2018, 4, 186-195.

48. Staubli, S.; Zweimüller, J. Does raising the early retirement age increase employment of older workers? J. Public Econ. 2013, 108, 17-32. [CrossRef]

49. Engels, B.; Geyer, J.; Haan, P. Pension incentives and early retirement. Labour Econ. 2017, 47, 216-231. [CrossRef]

50. Jimon, S.A.; Balteș, N.; Dumiter, F. Empirical Approaches upon Pension Systems in Central and Eastern European Countries. Triangle Assessment: Free Movement of People, Labor Market and Population Health Features. Studia Univ. "Vasile Goldis" Econ. Ser. 2020, 30, 1-21. [CrossRef]

51. Godinez-Olivares, H.; Del Carmen Boado-Penas, M.; Haberman, S. Optimal strategies for pay-as-you-go pension finance: A sustainability framework. Insur. Math. Econ. 2016, 69, 117-126. [CrossRef] 